\title{
Sugar Cane Juice Fermentation by Zymomonas mobilis CP4 Subjected to Inhibition by Ethanol and High Initial Concentration of Substrate
}

\author{
Marcia S. Tano*, João B. Buzato and Maria Antonia P. C. Celligoi \\ Departamento de Bioquímica - Universidade Estadual de Londrina, Caixa Postal 6001- CEP: 86051-900 - \\ Londrina $-P R$, Brazil
}

\begin{abstract}
Sugar cane juice fermentation by Z. mobilis CP4 subject to stress by ethanol and high concentration of sucrose was investigated. Supplementation with saponifiable portion of soybean oil deodourising destillate (SOD) at 5; 10 and $15 \mathrm{~mL} / \mathrm{L}$.The ethanol production resulted values of 15.91 ; 16.99 and $15.63 \mathrm{~g} / \mathrm{L}$ respectively. Values of Yp/s 0.35 ; 0.36 and 0.37 were achieved, which represented 20.69; 24.14 and $27.59 \%$ respectively higher when unsupplemented medium fermentation was carried out.
\end{abstract}

Key words: Zymomonas mobilis, fermentation, lipids, ethanol

\section{INTRODUCTION}

For the fuel ethanol industry to expand, there is a requiriment for search of more competitive ethanologenic microorganisms. Zymomonas mobilis has attracted the attention as a promising bacterium regarding improving ethanol production (Daugulis et al., 1997). Microorganisms are usually subjected to stressing conditions in ethanol destilleries. High sucrose concentrations and ethanol are a case in point (Falcão de Morais et al., 1993). Growth in high osmolar sugar solutions promotes by-products formation and the substrate is not fully metabolised. Ethanol has been established as the primary end product responsible for inhibiting fermentations (Moreau et al., 1997; Hallsworth, 1998). Tano (1999) has found that concentration of ethanol added in the fermentation medium as low as $25 \mathrm{~mL} / \mathrm{L}$ has an inhibitory effect. The fermetantion showed a long lag phase and it was incomplete as sugars were not fully metabolised.

Cells of microorganisms grown in the presence of ethanol show changes in the lipid composition of the cell plasma membrane (Hermans et al., 1991; Weir \& Chase Jr., 1995; Mizoguchi \& Hara, 1997). In Z. mobilis there are two possible mechanisms involving lipids to explain the ethanol tolerance. In the first mechanism, it is postulated that the high levels of cyclic lipids in the cell membranes protect the bacterium from the toxic effects of ethanol (Hermans et al., 1991). In the second mechanism, it is postulated that the high levels of cis-vaccenic acid in the phospholipids of the bacterial membrane protect the bacterium from ethanol toxicity (Ohta et al., 1981; Moreau et al., 1997).

There has been several publications dealing with the inhibitory effect of both ethanol and high initial concentration of substrate. These publications have used enrichment of fermentation medium such as salts, vitamin, proteins and lipids aiming fermentation improvement (Weir \& Chase Jr., 1995; Ohta et al., 1981; Mizoguchi \& Hara, 1997; Lawford \& Rousseau, 1997; Duarte et al., 1996). Minimization of cost are also associated with nutritional supplement for large scale production of ethanol (Lawford \& Rousseau, 1997).

Commercial dispersants and detergents are utilised when lipids are used as supplement in the culture medium (Ohta \& Hayashida, 1983; Duarte et al., 1996; Bruheim et al., 1997).

Deodourising destillate is a by-product of the soybean oil refining process. It is a lipid-rich material and its composition presents aldehydes, ketones, peroxides, hydrocarbons, tryglicerides and fatty acids. Its highly complex composition 
depends on soy bean variety and soy bean oil processing utilised. Free fatty acids and triglycerides constitute its saponifiable portion. (Almeida et al., 1994; Kao et al., 1998).

In the currenty study we have used the saponifiable portion of SOD as a nutritional supplement for ethanol production by Z. mobilis $\mathrm{CP} 4$, subjected to inhibitory fermentation conditions. Such conditions were achieved by adding ethanol into the culture medium and a high initial sucrose concentration.

\section{MATERIAL AND METHODS}

Microorganism: Bacterial strain used in this study was Zymomonas mobilis var. recifensis. It was maintained by montly transfer to the following medium $(\mathrm{g} / \mathrm{L})$ : sucrose 50 , yeast extract 5 , $\mathrm{KH}_{2} \mathrm{PO}_{4} 1,\left(\mathrm{NH}_{4}\right)_{2} \mathrm{SO}_{4} 1, \mathrm{MgSO}_{4}$ 0.5.

Fermentation medium contained $(\mathrm{g} / \mathrm{L})$ sugar cane juice with total reducing sugars adjusted to 150 , yeast extract 5, $\mathrm{KH}_{2} \mathrm{PO}_{4} 1, \mathrm{MgSO}_{4} 0.5,\left(\mathrm{NH}_{4}\right)_{2} \mathrm{SO}_{4}$ 1. The media in duplicates were supplemented with SOD at the following concentrations $(\mathrm{mL} / \mathrm{L})$ : 5; 10 and 15. These media concentrations were carried out in the three repetitions according statistical methodology by Barros Neto et al. (1996). The media were sterilised by autoclaving and after cooling, $25 \mathrm{~mL} / \mathrm{L}$ the ethanol GR was added. The saponifiable portion of SOD was extracted according to Rabassi (1997). A sample of $20 \mathrm{~g}$ of SOD was mixed with $40 \mathrm{~mL}$ of ethanol and then let it boil. After adding $20 \mathrm{~g}$ of $\mathrm{KOH}$ at $50 \%(\mathrm{~W} / \mathrm{V})$, it was refluxed. After cooling $\mathrm{HCl}$ was added for neutralization

The total reducing sugar concentration of $150 \mathrm{~g} / \mathrm{L}$ in the cane juice and lipid supplementation were utilised according to statistical method (Barros Neto et al., 1996). The determination of biomass was by measuring the absortion at $605 \mathrm{~nm}$ and the corresponding dry weight was obtained from a standard plot (Duarte et al., 1996). Reducing sugars and total reducing sugars were assayed by the method of Somogyi (1945) and Nelson (1944). Samples for total reducing sugars determination were treated according to Diez \& Yokoya (1996).
Ethanol concentrations were analysed using a gas chromatograph CG-17A SHIMADZU, with DBwax columm with $210^{\circ} \mathrm{C}$ injector temperature (Diez \& Yokoya, 1996).

\section{RESULTS AND DISCUSSION}

Table I and Figures 1-4 show the results of biomass, ethanol, values for total reducing sugars and reducing sugars from cultures of $Z$. mobilis CP4. When the medium with no-lipid supplement was used, ethanol production reached $13.89 \mathrm{~g} / \mathrm{L}$ (Fig. 1). However a gradually raising in the ethanol production was observed when the lipidsupplement media were used. Ethanol concentrations of $15.91,16.99$ and $15.63 \mathrm{~g} / \mathrm{L}$ (Figures 2-4) were found when the medium was enriched with SOD at concentration of 5, 10 and $15 \mathrm{~mL} / \mathrm{L}$ respectively. These results were 14.54 , 22.31 and $12.52 \%$ superior when the medium with supplementation was used. Increased values of ethanol production have also been found by other authors. Weir \& Chase Jr. (1995) have reported values 12\% higher and Ohta et al. (1981) have achieved values $20 \%$ superior when the culture media were enriched with proteolipids.

In Z. mobilis when both substrate metabolism and ethanol production continue while there is a cessation of cellular growth, it is said that growth is uncoupled. Joachimsthal et al. (1998) have reported an increased ethanol excretation in the presence of acetate while growth was negligible. Calazans et al. (1990) have demonstrated abscence of growth during ethanol formation when there was a lack of mineral salts in the medium fermentation. This work suggested that supplementation of medium with SOD could also uncouple growth from ethanol production. This was supported by biomass values which were lower and yet ethanol concentrations were higher when the comparison is made with results of fermentation whithout SOD supplementation. When SOD-supplemented media were used the biomass values were $1.36 ; 1.23$ and $1.19 \mathrm{~g} / \mathrm{L}$ (Table I) at 5,10 and $15 \mathrm{~mL} / \mathrm{L}$ of SOD added to the medium, respectively. These values of biomass are $22.29 ; 29.71$ and $32.00 \%$ lower than those where no SOD was used. 
Table 1. Comparative kinetic parameters for sugar cane juice fermentation added with $25 \mathrm{~mL} / \mathrm{L}$ of ethanol by $Z$. mobilis CP4 (28 $\mathrm{C}, 180 \mathrm{rpm}, 48$ hours).

\begin{tabular}{llcccc}
\hline & $\begin{array}{c}\text { Sugar cane } \\
\text { juice }\end{array}$ & \multicolumn{1}{c}{} & & \\
& & Lipids: & Lipids: & Lipids: & Lipids: \\
& 0 & $5 \mathrm{~mL} / \mathrm{L}$ & $10 \mathrm{~mL} / \mathrm{L}$ & $15 \mathrm{~mL} / \mathrm{L}$ \\
\hline $\mathrm{TRS}_{0}$ & $\mathrm{~g} / \mathrm{L}$ & 151,74 & 147,49 & 151,53 & 147,49 \\
$\mathrm{TRSc}$ & $\mathrm{g} / \mathrm{L}$ & 48,03 & 45,49 & 47,48 & 41,89 \\
$\mathrm{RS}_{0}$ & $\mathrm{~g} / \mathrm{L}$ & 15,30 & 14,98 & 13,84 & 14,86 \\
$\mathrm{RSf}$ & $\mathrm{g} / \mathrm{L}$ & 55,10 & 70,73 & 71,15 & 70,86 \\
{$[\mathrm{X}]$} & $\mathrm{g} / \mathrm{L}$ & 1,75 & 1,36 & 1,23 & 1,19 \\
{$[\mathrm{P}]$} & $\mathrm{g} / \mathrm{L}$ & 13,89 & 15,91 & 16,99 & 15,63 \\
$\mathrm{Yx} / \mathrm{s}$ & $\mathrm{g} / \mathrm{g}$ & 0,036 & 0,029 & 0,026 & 0,028 \\
$\mathrm{Yp} / \mathrm{s}$ & $\mathrm{g} / \mathrm{g}$ & 0,29 & 0,35 & 0,36 & 0,37 \\
$\mathrm{Yecon}$. & $\%$ & 16,99 & 20,02 & 20,81 & 19,66 \\
\hline
\end{tabular}

When the medium without SOD-supplementation was used, a value of 0.036 for $\mathrm{Yx} / \mathrm{s}$ was found. This value was similar to that of Lee et al. (1981) when glicose at $100 \mathrm{~g} / \mathrm{L}$ and temperature of $30^{\circ} \mathrm{C}$ were used. However when SOD-enriched medium with 5,10 and $15 \mathrm{~mL} / \mathrm{L}$ was used, the values of $0.029,0.026$ and 0.028 were found. These values were similar when high concentration of substrate were used (Rogers et al., 1982). Lower values of $\mathrm{Yx} / \mathrm{s}$ have been presented by other authors (Diez \& Yokoya, 1996).

When the medium without supplementation was used a value of 0.29 for $\mathrm{Yp} / \mathrm{s}$ was found. However, when enriched medium with 5,10 and $15 \mathrm{~mL} / \mathrm{L}$ was used, higher values were found for $\mathrm{Yp} / \mathrm{s} 0.35$, 0.36 and 0.37. Similar results have been achieved by Toran-Diaz et al. (1983) when high concentration of fructose was used. Toran-Diaz et al. (1983) have presented values of 0.38 and 0.34 for $\mathrm{Yp} / \mathrm{s}$. When medium was supplemented with yeast extract even higher values were found by Favela Torres \& Baratti (1987).

When the medium without SOD was used, a value of $16.99 \%$ for Yecon. was found. However, values of $20.02,20.81$ and $19.66 \%$ were achieved. These values are lower to that of Duarte et al. (1996). Duarte et al. (1996) have also utilised soybean oil deodourising destillate and achieved $22.40 \%$ for Yecon.. However ethanol had not been added in the culture medium.
Incomplete fermentations have been reported when high initial substrate concentrations were used (Doelle \& Greenfield, 1985; Daugulis et al., 1997). Such fermentations accumulated high levels of reducing sugars (Figures 1-4) (Calazans et al., 1990). Lyness \& Doelle (1981) have suggested that when initial sucrose concentration was high there was a low value for Yecon. due to poor utilisation of fructose rather than lack of hydrolysis of sucrose. These considerations are in aggreement with our results as the final reducing sugar values are high.

In addition to inhibition effects of ethanol (Calazans et al., 1990), several authors have concluded that medium composition might also reduce the total amount of carbon available for ethanol formation and lowering fermentation efficiencies. The low efficiencies obtained in this study could probably be ascribe to the presence of certain compounds in the sugar cane juice which could be inhibitory to growth and ethanol production by Z. mobilis (Doelle et al., 1990; Duarte et al., 1996). However the results in this study, utilising sugar cane juice with supplementation of SOD, have improved the catabolic activity of Z. mobilis which has led to an improvement of ethanol yield. 


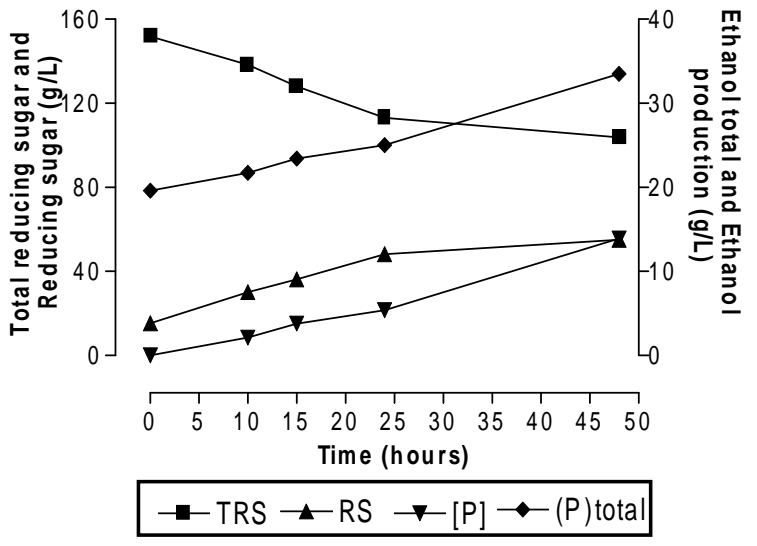

Figure 1. Batch fermentation of sugar cane juice medium added with $25 \mathrm{~mL} / \mathrm{L}$ of ethanol by $Z$. mobilis.

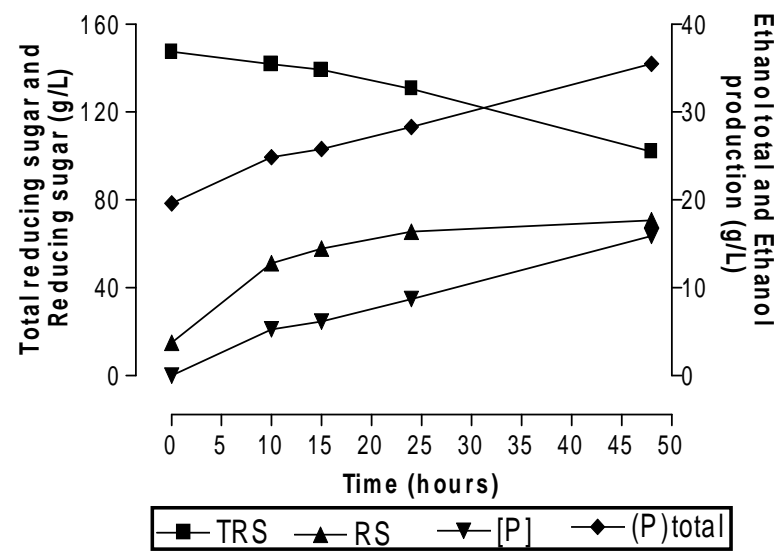

Figure 2. Influence of $\mathrm{SOD}(5 \mathrm{~mL} / \mathrm{L})$ on batch fermentation of sugar cane juice medium added with $25 \mathrm{~mL} / \mathrm{L}$ of ethanol by $Z$. mobilis.

\section{NOMENCLATURE}

$\mathrm{TRS}=$ total reducing sugars; $\mathrm{TRS}_{0}=$ initial total reducing sugars; TRSc $=$ consumption of total reducing sugars; $\mathrm{RS}=$ =reducing sugars; $\mathrm{RS}_{0}=$ initial reducing sugars; $\mathrm{RSf}=$ final reducing sugars; $[\mathrm{X}]=$ biomass production; $[\mathrm{P}]=$ ethanol production; $(\mathrm{P})$ total = ethanol total (added+production); $\mathrm{Yp} / \mathrm{s}=$ ethanol yield coefficient $(\mathrm{g}$ ethanol/g glucose consumed); Yx/s=biomass yield coefficient (g biomass/g glucose consumed); Yecon. $($ fermentation efficiency $)=[$ ethanol $] /(0.511$ . $\left.\mathrm{TRS}_{0}\right)$

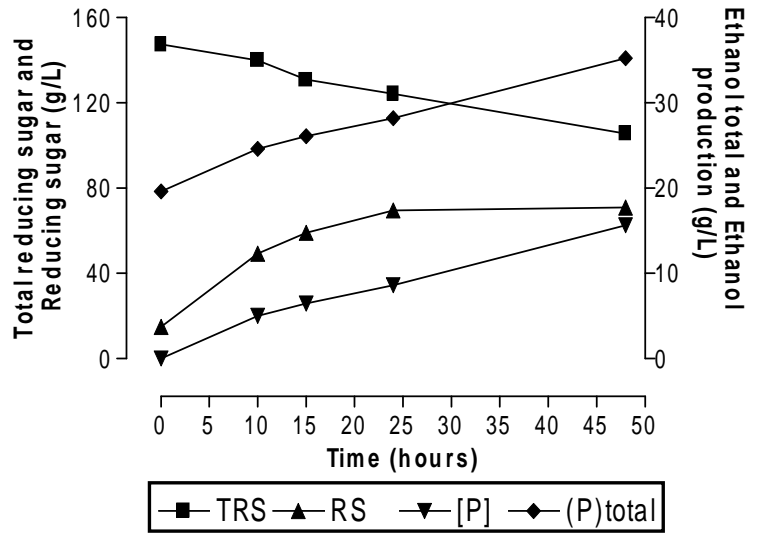

Figure 3. Influence of $\mathrm{SOD}(10 \mathrm{~mL} / \mathrm{L})$ on batch fermentation of sugar cane juice medium added with $25 \mathrm{~mL} / \mathrm{L}$ of ethanol by Z. mobilis.

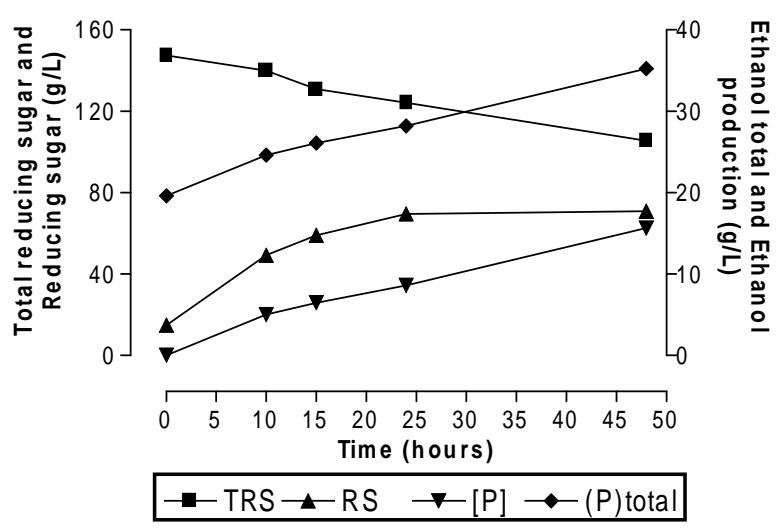

Figure 4. Influence of $\mathrm{SOD}(15 \mathrm{~mL} / \mathrm{L})$ on batch fermentation of sugar cane juice medium added with $25 \mathrm{~mL} / \mathrm{L}$ of ethanol by Z. mobilis.

\section{ACKNOWLEDGMENTS}

Marcia S. Tano is grateful for the financial support given by CAPES. The authors are grateful to Ieda Spacinio Scarmínio for the statistical analysis.

\section{RESUMO}

Este trabalho investigou a fermentação de caldo de cana-de-açúcar por células de $Z$. mobilis submetidas ao estresse pelo etanol e elevada concentração inicial de sacarose. Foi utilizado como suplementação a porção 
saponificável do destilado da desodorização de óleo de soja (SOD) nas seguintes concentrações: 5,10 e $15 \mathrm{~mL} / \mathrm{L}$. Os valores de produção de etanol foram respectivamente: 15,$91 ; 16,99$ e $15,63 \mathrm{~g} / \mathrm{L}$. Os valores de $\mathrm{Y}_{\mathrm{p} / \mathrm{s}}$ foram: 0,$35 ; 0,36$ e 0,37 , os quais representam respectivamente: 20,$69 ; 24,14$ e $27,59 \%$, superiores daquele cujo meio não foi suplementado.

\section{REFERENCES}

Almeida, M. E. M.; Gusman, E. C.; Carvalho, P. R. N.; Rusig, O. (1994), Avaliação de destilado da desodorização do óleo de soja para a extração de vitamina E. Arq. Biol. Tecnol., 37(4): 1003-1011

Barros Neto, B. de; Scarmínio, I. S.; Bruns, R. E. (1996), Planejamento e otimização de experimentos. 2 ed., Campinas: Ed. da UNICAMP, 1996. 299

Bruheim, P.; Bredholt, H.; Eimhjellen, K. (1997), Bacterial degradation of emulsified crude oil and the effect of various surfactants. Can. J. Microbiol., 43: $17-22$

Calazans, G. M. T.; Eugênia, M. R.; Falcão de Morais, F. O. (1990), Efeito da concentração de glicose, do $\mathrm{pH}$ inicial e da temperatura na fermentação alcoólica por Zymomonas mobilis ZAP. Arq. Bio. Tecnol., 33(2) 439-455

Daugulis, A. J.; McLellan, P. J.; Li, J. (1997), Experimental investigation and modeling of oscillatory behavior in the continuous culture of Zymomonas mobilis. Biotechnol. Bioeng., 56(1): 99105

Diez, J. C.; Yokoya, F. (1996), Efeito da temperatura e pH na produção de etanol e levana durante a fermentação de sacarose por Zymomonas mobilis. Arq. Biol. Tecnol., 39(3): 129-137

Doelle, H. W.; Greenfield, P. H. (1985), The production of ethanol from sucrose using Zymomonas mobilis. Appl. Microbiol. Biotechnol., 22: 405-410

Doelle, M. B.; Greenfield, P. F.; Doelle, H. W. (1990), Effect of mineral ions on ethanol formation during sugar cane molasses fermentation using Zymomonas mobilis ATCC 39679. Proc. Biochem. Intern., 151156

Duarte, J. C.; Celligoi, M. A. P. C.; Buzato, J. B. (1996), Fermentação alcoólica por Zymomonas mobilis CP4 ou por Saccharomyces cerevisiae em caldo de cana com e sem suplemento lipídico. Arq. Biol. Tecnol., 39(2): 285-293

Falcão de Morais, J. O.; Rios, E. M. M. M.; Calazans, G. M. T.; Lopes, C. E. (1993), Zymomonas mobilis research in the Pernambuco Federal University. $J$. Biotechnol., 31: 75-91
Favela Torres, E.; Baratti, J. (1987), The effect of pH, temperature and sucrose concentration on high productivity continuous ethanol fermentation using Zymomonas mobilis. Appl. Microbiol. Biotechnol., 27: $121-128$

Hallsworth, J. E. (1998), Ethanol-induced water stress in yeast. J. Ferment. Bioeng., 85(2): 125-127

Hermans, M. A. F.; Neuss, B.; Sahm, H. (1991), Content and composition of hopanoids in Zymomonas mobilis under various growth conditions. $J$. Bacteriol., 173(17); 5592-5595

Joachimsthal, E. Haggett, K. D.; Jang, J-H.; Rogers, P. L. (1998), A mutant of Zymomonas mobilis ZM4 capable of ethanol production from glucose in the presence of high acetate concentrations. Biotechnol. Lett., 20(2) 137-142

Kao, J-W.; Hammond, E. G.; White, P. J. (1998), Volatile compounds produced during deodorization of soybean oil and their flavor significance. JAOCS., 75(9): 1103-1107

Lawford, H. G.; Rousseau, J. D. (1997), Corn steep liquor as a cost-effective nutrition adjunct in highperformance Zymomonas ethanol fermentations. Appl. Biochem. Biotechnol., 63-65: 287-304

Lee, K. J.; Skotnicki, M. L.; Tribe, D. E.; Rogers, P. L. (1981), The effect of temperature on the kinetics of ethanol production by strains of Zymomonas mobilis. Biotechnol. Lett., 3(6): 291-296

Lyness, E.; Doelle, H. W. (1981), Ethanol production from cane juice by Zymomonas mobilis. Biotechnol. Lett., 3(5): 257-260

Mizoguchi, H.; Hara, S. (1997), Ethanol-induced alterations in lipid composition of Saccharomyces cerevisiae in the presence of exogenous fatty acid. $J$. Ferm. Bioeng., 83(1): 12-16

Moreau, R. A.; Powell, M. J.; Fett, W. F.; Whitaker, D. (1997), The effect of ethanol and oxygen on the growth of Zymomonas mobilis and the levels of hopanoids and other membrane lipids. Cur. Microbiol., 35: 124-128

Nelson, N. A. (1944), Colorimetric adaptation of the Somogyi method for determination of glucose. Biochem., 153: 376-380

Ohta, K.; Hayashida, S. (1983), Role of Tween 80 and monoolein in a lipid-sterol-protein complex which enhances ethanol tolerance of sake yeasts. Appl. Envir. Microbiol., 46: 821

Ohta, K.; Supanwong, K.; Hayashida, S. (1981), Environmental effects on ethanol tolerance of Zymomonas mobilis. J. Ferment. Technol., 59(6): 435-439

Rabassi, R. J. (1997), Extração dos tocoferóis a partir do destilado da desodorização do óleo de soja. 47 p. (Monografia apresentada ao Curso de Especialização em Bioquímica Aplicada, Universidade Estadual de Londrina) 
Rogers, P. L.; Skotnicki, M. L.; Tribe, D. E. (1982), Ethanol production by Zymomonas mobilis. Adv. Biochem. Eng., 23: 37-84

Somogyi, M. A. (1945), A new reagent for the determination of sugar. Biol. Chem., 160: 61-68

Tano, M. S. (1999), Utilização da porção lipídica saponificável do destilado da desodorização do óleo de soja na fermentação da garapa por Zymomonas mobilis CP4 induzida ao estresse. 53p. (Dissertação apresentada ao Curso de Mestrado em Microbiologia, Universidade Estadual de Londrina).
Toran-Diaz, C.; Delezon; Baratti, J. (1983), The kinetcs of ethanol production by Zymomonas mobilis on fructose medium. Biotechnol. Lett., 5(6): 409412

Weir, P. M.; Chase Jr., T. (1995), Effect of proteolipid on Zymomonas fermentation of $25 \%$ glucose media. J. Ind. Microbiol., 15: 442-445

Received: September 29, 1999; Revised: December 27, 1999; Accepted: April 07, 2000. 